\title{
MENCARI BENANG MERAH KONSTITUSIONAL ANTARA KEBEBASAN BERAGAMA DAN PENODAAN AGAMA; DARI KONSEP BLASPHEMY LAW HINGGA PELARANGAN AHMADIYAH DI INDONESIA
}

\author{
Agus Triyanta \\ Fakultas Hukum Universitas Islam Indonesia \\ aqustrivanta@uii.ac.id dan trivantaaqus@vahoo.com
}

\begin{abstract}
Abstrak
The freedom of expression, of embracing any religion and beliefs as well, which are guarantted by many documents in human rights and constitutions in a lot of countries, including the Republic of Indonesia, finally must be considered as something which is not absolute in nature. The interpretation on the favor of such absoluteness will certainly carry the effects of the freedom and liberty of particultas person or group of people. In this contex, the freedon entails to be proportionally set out in order that such freedom will never violate or humiliate the freedom of others. The case of Ahmadiyyah is the suitable example for it. This article seeks to discuss woh the blasphemy law wich applies in modern world indicates the inabsoluteness of the religious freedom.
\end{abstract}

Keywords: constitution, religion, ahmadiyyah

\section{PENDAHULUAN}

Lebih dari dua dekade yang lalu, di Inggris, seorang sastrawan yang bernama Salman Rusdhie menulis sebuah karya yang berjudul The Satanic Verses. ${ }^{1}$ Dalam karyanya tersebut, diceritakan yang pada intinya ada seorang tokoh yang bernama "Mahound" (dengan segala konteks yang diberikannya dapat ditebak bahwa yang dimaksud tidak lain adalah Nabi Muhammad saw) yang menyampaikan ajaran dalam kitab suci. Ajaran baru itu diperolehnya, menurut Salman Rusdie, bukanlah dari wahyu (revelasi), namun adalah bisikan syetan. Di samping itu, juga disebutkan bahwa isteri Nabi tersebut, yang bernama 'Ayesha' adalah seorang pelacur. ${ }^{2}$

Kasus ini kemudian memicu protes massif, dan Pemerintah Inggris di samping tidak bisa menyalahkan Rusdie karena karyanya, dengan mendasarkan pada kebebasan berpendapat, namun di sisi lain juga dapat 'berempati' kepada umat Islam yang merasa tersinggung perasaannya. Konsep blasphemy law kemudian menyeruak, meski akhirnya gagal juga untuk diterapkan pada kasus Salman Rushdie ini.

Blasphemy law, adalah hukum penghinaan agama, yang ini menjadi instrumen dalam menjaga agama (khususnya Kristen di Barat) dari berbagai bentuk penghinaan ${ }^{3}$, hukum ini diterapkan dalam banyak kasus di negara Barat, untuk melindungi hak beragama seseorang. Atas dasar itulah, maka di dunia Barat pun, tindakan yang dapat dinilai mengarah pada penghinaan terhadap suatu ajaran agama, tetap dilarang, sekalipun atas dalih bahwa hal itu adalah keyakinan yang dianut seseorang atau kelompok orang.

\footnotetext{
Satanic Verses: "Freedom of Speech Does not Offer Right to Blaspheme," by Firoz Osman, dalam Media Monitors Network, dalam, www.mediamonitors.net, diakses 11 September 2011.

2. All A Mazrui, The Satanic Verses or a Satanic Novel? Moral Dilemmas of the Rushdie Affair, him., 5-6.dalam www.angelfire.com rebellion2...SalmanRushdie satanic verses.pdf. diakses 11 September 2011.

3 L. Bennett Graham, Defamation Of Religions: The End Of Pluralism?, dalam, www.law.emorv.edu Diakses 9 Maret 2010, hlm. 81.
} 
Meski demikian, hukum tentang penghinaan ajaran agama hari ini juga banyak disorot, karena ada juga gerakan yang berkeinginan untuk menghapuskan blasphemy law ini ${ }^{4}$. Antara kebebasan beragama dan penodaan beragama, dalam masyarakat yang sedang mengalamai eskalasi kesadaran akan hak asasi dan kebebasan seperti Indonesia, bukanlah hal yang sederhana. Dalam kasus gerakan Ahmadiyah misalnya, dan tidak menutup kemungkinan akan adanya aliran atau gerakan lain yang berpotensi untuk mengemuka, hal tersebut perlu pemetaan yang hati-hati sehingga apapun putusan dan tindakan konstitusional terhadapnya, dalam diberikan dan dilakukan dalam konteks yang proporsional.

\section{AKAR IDEOLOGIS PENGAKUAN AGAMA SEBAGAI HAK ASASI}

Agama merupakan bagian yang tidak terpisahkan bagi kehidupan sekelompok manusia, termasuk sebuah bangsa. Perunutan historis menunjukkan bahwa agama memang memiliki hubungan dilektis dengan peradaban manusia. Memang, dalam pandangan antropolgis, pada awalnya, agama adalah produk dari peradaban, ${ }^{5}$ meski demikian,dalam perkembangannya kemudian agama memerankan penting bagi pembentukan peradaban itu sendiri. Lain dari itu, dan ini yang dinilai lebih diterima secara luas, agama bukanlah produk peradaban manusia. Agama diterima oleh manusia melalu proses wahyu, yang kemudian, setelah mengalami internalisasi dalam diri manusia, akan membentuk karakter manusia dalam sebuah format tertentu yang pada gilirannya kemudian mewarnai peradabannya.

Sehingga, dapatlah dikatakan bahwa agama adalah sesuatu yang inheren dengan kehidupan manusia. Malah, sementara agama berpandangan bahwa agama adalah salah satu spot di antara berbagai aspek dalam diri manusia. Atas dasar alasan ini maka, pertanyaanpertanyaan yang bersifat ultimate question terhadap misteri kosmos dan misteri manusia itu sendiri adalah pertanyaan yang memang akan selalu ada dan terjadi dalam diri manusia. Dan itulah yang disebut dengan god spot. ${ }^{6}$

Karena ketidakniscayaan pemisahan antara manusia dan agama itulah, maka agama kemudian mendapatkan posisi tersendiri dalam berbagai traktat atau kovenan dan piagampiagam tentang hak-hak manusia. ${ }^{7}$ Peran tersebut selalu saja memberikan garansi bahwa keberagamaan seseorang adalah sebuah hak yang harus dijamin dan dijaga. Piagam Madinah, yang diyakini sebgai suatu bentuk konstitusi tua, juga memberikan hak beragama untuk selain komunitas Muslim. ${ }^{8}$ Magna Charta yang lahir di Inggris berabad-abad mendahului UDHR juga sudah memberikan penegasan tentang kebebasan beragama. ${ }^{9}$

\section{KEBEBASAN; RELATIF ATAU ABSOLUT}

Sejujurnya, tidak pernah terdapat kebebasan absolut dalam komunitas manapun juga. Kebebasan absolut hanya dapat diniscayakan jika manusia memisahkan dirinya dari eksistensinya sebagai makhluk sosial, dengan kata lain seseorang tidak lagi hidup dalam kehidupan komunal, dia menyendiri yang karenanya segala perilakunya tidak akan berimplikasi

4 Paul Kearns, The End of Blasphemy Law, dalam Amius Curiac Issue 76, Winter 2008. Him. 25 dalam, www.sasspace.sas.ac.uk, diakses, 9 maret 2010

5 Charles Davis's question in Religion Making Society ( Cambridge :Cambridge University Press, 1994) hlm. $4 \mathrm{dan}$, Raymond Firth, Religion, a Humanist Interpretation (London : Routledge, 1996), hlm. 10

6 Penelitian yang dilakukan oleh Michael Persinger di awal th 1990-an dan VS Ramachandran dan tim dari California University mengungkap adanya God Spot dalam otak manusia sebagai spiritual center dalam otak manusia. Ary Ginanjar Agustian, Emotional, Spiritual Quotient, Jakarta: Arga Publishing, 2010, him. 11.

7 Misalnya saja, "Universal Declaration of Human Rights," dalam, lan Brownlie, Basic Documents on Human Rights, Oxford: Offord University Press, 1992.hlm. 21-27. Shiddiqi, N, Piagam Madinah, Yogyakarta: Mentari Masa 1989, Bill of Rights di Inggris belum menyebut tentang kebebasan agama, hanya membatasi kekuasaan raja. The Hutchinson Dictionay of World History (Oxford: Helicon Poblishing, 1998) hlm.69, 369. The Magna Charta, The Original Version of this Text was Rendered into HTML by Jon Roland of the Constitution. Society, dalam www.constitution.ora/enal Akses 5 Mei 2014.

Shiddiqi, lbid

9 Brownlie, Ibid 
pada komunitas dalam mana dia berada. Tetapi pertanyaannya, apakah hal itu mungkin. Sangat jelas, jawaban akan mengatakan bahwa hal itu tidak akan pernah terjadi.

Mengikuti alur logika di atas, maka sebenarnya perjuangan atau upaya apapun namanya yang bertujuan untuk mewujudkan liberasi yang absolut adalah perbuatan yang tidak akan mungkin berbuah. Di sinilah sebenarnya ufuk bagi kebebasan itu sendiri yang mengharuskan orang mulai kembaii pada pemahaman bahwa kebabasan itu adalah relatif. Ungkapan klisenya adalah; "bebas dalam keterbatasan"10.

Karena itulah, kebebasan yang dapat diciptakan sebenarnya adalah kebebasan yang relatif, ialah kebebasan yang dapat memfasilitasi setiap orang untuk berekspresi dan berkreasi dalam spektrum yang tidak mengurangi hak orang lain. ${ }^{11}$ Jika kebebasan dilakukan sedemikian rupa sehingga merugikan orang lain atau menjadikan orang lain tidak memiliki kebebasan, maka itu berarti melakukan kediktatoran atas nama kebebasan, suatu hal yang sangat ironis bagi masyarakat yang sedang memperjuangkan nilai-nilai kebebasan.

\section{KEBEBASAN BERAGAMA VS. PELECEHAN AGAMA}

Antara kebebasan beragama dan pelecehan terhadap agama hanya dibatasi oleh sekat yang sangat tipis. Ketika seseorang berbuat sesuatu dengan mengatasnamakan agama tertentu dapat saja hal tersebut dikatakan sebagai sesuatu yang bersifat kepentingan individu, karena memang benar bahwa agama dan keyakinan merupakan masalah yang sangat privat. Tetapi justeru karena agama dan keyakinan itu terlalu privat, yang ditandai dengan keterkaitan emosional yang cukup tinggi, maka justeru agama dan keyakinan itu merupakan wilayah yang sangat rawan untuk terjadinya konflik.

Dan karenanya, perlu dicatat, bahwa konflik yang bersumber dari agama atau keyakinan merupakan konflik yang bersifat komplikatif, karena menyangkut sesuatu yang abstrak dan konkrit sekaligus. Agama adalah sebuah wilayah yang sakral, sementara sakralitas itu sendiri dibentuk oleh kayakinan agama itu juga. Konsep sakral dan profan yang dibentuk oleh sebuah agama menjadikan pemeluknya memiliki cara pandang tersendiri yang unik atas setiap fenomena atau alam kehidupan ini (worldview/ we/stanchaung). ${ }^{12}$

Maka suatu tindakan beragama yang sangat bebas, yang dilakukan tanpa memperhatikan keyakinan orang lain, berpotensi untuk tersulutnya apa yang disebut dengan "penghinaan agama." Hal ini disadari bukan saja orang masyarakat di negara berkembang, namun ini merupakan suatu hal yang jamak di berbagai negara. Buktinya, konsep blasphemy merupakan suatu hal yang ada dalam berbagai regulasi yang ada. ${ }^{13}$

\section{KASUS AHMADIYAH DI INDONESIA}

Kemunculan Ahmadiyah bukan saja khas Indonesia. Ahmadiyah merupakan aliran keagamaan yang ada di berbagai negara. Sebagai sebuah gerakan agama, Ahmadiyah memiliki kredo (sistem keyakinan) dan ritus (sistem seremoni) tersendiri. Permasalahan utama terkait dengan Ahmadiyah adalah bahwa Ahmadiyah mengidentifikasi diri sebagai agama Islam, sedangkan dalam kedua sistem di atas kredo maupun ritualnya terdapat perbedaan dengan mainstream ajaran Islam yang diterima (disepakati). ${ }^{14}$

${ }_{10} \mathrm{Jr}$, W. Cole Durham, The Right to Autonomy in Religious Affairs: A Comparative View, www.strasbourgconsortium.org hlm. 2 dan 10. Akses, 6 Mei 2014

11 lbid

12 Peter L Berger, The Sacred Canopy, Elements of a Sociological Theory of Religion ( New York-London : Anchor Book Doubleday, 1990) juga, William E Paden, Religious Worlds, The Comparative Study of Religion (Boston : Beacon Press, 1998)

${ }^{13}$ Untuk diskusi tentang Blasphemy di dunia barat, lihat footnote no 3 dan 4

14 Perbedaannya menganggap bahwa Mirza Ghulam Ahmad adalah Nabi. Dia juga mendapat wahyu. Hal 
Sebenarnya Islam juga bukanlah agama yang tidak dapat menerima perbedaan. Perbedaan adalah sebuah fakta dalam banyak agama, termasuk di dalam agama Islam, namun Islam sendiri menegaskan bahwa perbedaan tidak dapat terjadi dalam hal-hal yang prinsip..$^{15}$ Adalah sesuatu yang mesti disadari, bahwa karena agama meyakini adanya wahyu, hal yang wajar juga apabila kemudian dalam pemaknaan wahyu tersebut mengalami proses diversifikasi. Ketika pemaknaan masih hanya dilakukan dalam tingkatan nabi, seseorang yang dalam berbagai agama diyakini sebagai mediator yang diberikan otoritas ilahiah untuk menafsir wahyu, penganut agama masih secara konsensus menerimanya.

Namun sebagai akibat dari berkembangnya kehidupan yang menghadirkan fakta-fakta dan tantangan-tantangan baru dalam kehidupan, penafsiran (interpretasi) dan penafsiranulang (reinterpretasi) agama akan terus terjadi. Sampai dalam tataran ini maka agama selalu saja memiliki perubahan dan perkembangan dalam tafsir terhadap agama. Namun yang harus ditegaskan di sini adalah bahwa mesti saja selalu ada konsep tafsir yang bersifat mainstream dan diterima oleh mayoritas.

Dalam konteks seperti inilah, Ahmadiyah meyakini kredo dan ritus yang memiliki perbedaan dengan mainstream. Perbedaan tersebut adalah dalam hal kepercayaan terhadap Mirza Ghulam Ahmad sebagai Nabi serta Aurat Muhammadiyah sebagai sebuah ajaran kitab suci.

Persoalan perbedaan ini sangat mendasar dalam ajaran Islam. Masalahnya bukan saja karena minoritas melawan mayoritas, yang kemudian dapat diberikan penyelesaian dengan mainstreaming Ahmadiyah, atau menjadikan keyakinan Ahmadiyah sebagai sesuatu yang mainstream juga. Tetapi masalah yang lebih urgen adalah persepsi orang Islam di luar Ahmadiyah yang menilai Ahmadiyah telah melanggar sistem kredo dan sistem ritus dalam Islam, sehingga meskipun Ahmadiyah akan menjadi mainstream, tetap saja Ahmadiyah akan 'dilawan' oleh umat Islam yang non Ahmadiyah.

Penolakan ini menunjukkan ketidakmungkinannya aliran Ahmadiyah untuk ditolerir. Ketika ketidakmunkingan ditolerir ini tetap berjalanan dan di sisi yang lain Ahmadiyah tetap menyatakan sebagai pemeluk Islam juga, maka sampailah pada level 'penghinaan' terhadap penganut agama. Dalam konteks ini, Ahmadiyah telah melakukan penghinaan terhadap Islam. Penghinaan ini dirasakan oleh umat Islam (mainstream) karena apa yang diyakini sebagai prinsip utamanya telah dilanggar oleh orang yang menyatakan sebagai penganut Islam juga.

Maka pelarangan Ahmadiyah bukan saja karena memang keberadaan Penetapan Presiden Republik Indonesia Nomor 1 Tahun 1965 Tentang Pencegahan Penyalahgunaan Dan/Atau Penodaan Agama, atau yang secara singkat sering idsebut dengan PNPS no 1 tahun $1965,{ }^{16}$ tetapi juga memang telah ada apa yang disebut dengan Surat Keputusan Tiga Menteri, yakni, surat keputusan yang dikeluarkan Menteri Agama, Jaksa Agung, dan Menteri Dalam Negeri Republik Indonesia, yang isinya berkaitan dengan Peringatan dan Perintah

ini jelas bertentangan dengan ajaran yang sangat mendasar dalam agama Islam yang dianut oleh mayoritas dan diniai sebagai keyakinan dasar. Lihat, Shaikh Khurshld Ahmad (Translation, Zakaria Virk ), A Brief History of Ahmadiyya Muslim Community (For Ahmadi Children), dalam, htto://www.alislam.oral, diakses 11 September 2011.

${ }^{15}$ Anjuran untuk menghindari perpecahan misalnya, QS. Ali Imran: 103. 103. "Dan berpeganglah kamu semuanya kepada tali (agama) Allah, dan janganlah kamu bercerai berai, dan ingatlah akan nikmat Allah kepadamu ketika kamu dahulu (masa Jahiliyah) bermusuh-musuhan, Maka Allah mempersatukan hatimu, lalu menjadilah kamu Karena nikmat Allah, orang-orang yang bersaudara; ....... Juga, QS:Al-Rum: 31-32: “ Dengan kembali bertaubat kepada-Nya dan bertakwalah kepada-Nya serta Dirikanlah shalat dan janganlah kamu termasuk orang-orang yang mempersekutukan Allah. Yaitu orang-orang yang memecah-belah agama merekadan mereka menjadi beberapa golongan. tiap-tiap golongan merasa bangga dengan apa yang ada pada golongan mereka."

${ }_{16}$ Penetapan Presiden Republik Indonesia Nomor 1 Tahun 1965 Tentang Pencegahan Penyalahgunaan Dan/Atau Penodaan Agama, sebagaimana yang dimuat dalam Lembaran Negara Republik Indonesia Tahun 1965 Nomor 3. 
Kepada Penganut, Anggota, Dan/Atau Anggota Pengurus Jemaat Ahmadiyah Indonesia (JAI) Dan Warga Masyarakat. ${ }^{17}$

\section{ANALISA KONSTITUSIONAL}

Di Indonesia, kebebasan agama diatur dalam konstitusi. Dalam Undang-Undang Dasar 1945, kebebasan agama diatur secara detail, yang pada intinya bahwa kemerdekaan agama merupakan hak-hak utama yang diproteksi secara kuat. Bahkan, dapat dikatakan bahwa telah ada kecenderungan liberal bagi jaminan beragama. Kecenderungan liberal dimaksud adalah bahwa keistimwaan pada agama-agama tertentu, termasuk agama mayoritas, dapat dikatakan tidak ada, artinya bahwa semua agama memiliki kedudukan yang sama di depan konstitusi.

Ayat (1) dan (2) pasal 28E UUD 1945 menyatakan: ${ }^{18}$

(1) Setiap orang bebas memeluk agama dan beribadat menurut agamanya,memilih pendidikan dan pengajaran, memilih pekerjaan, memilih kewarganegaraan, memilih tempat tinggal diwiiayah negara dan meninggalkannya, serta berhak kembali.

(2) Setiap orang atas kebebasan meyakini kepercayaan, menyatakan pikiran dan sikap, sesuai dengan hati nuraninya.

Pernyataan tersebut telah memberikan implikasi bahwa orang dapat sebebas-bebasnya untuk memeluk sebuah agama dan atau kepercayaan. Sehingga, jika tidak dipahami secara utuh dengan menyertakan latar belakang dan konteks historisnya, boleh jadi kesimpulan dari aturan tersebut adalah bahwa seseorang bebas menganut agama dan aliran mana saja yang dikehendaki.

Dengan semata-mata menekankan aspek kebebasannya, maka agama apapun dan aliran kepercayaan apapun akan dapat diadvokasikan agar dilegalkan di negara ini. Karena itu pembatasan hanya agama tertentu yang dapat dianut di Indonesia tidak lagi merupakan suatu ketentuan yang dipertahankan lebih lama lagi. Namun, dengan memperhatikan konteks sosial dan historis, tentunya tidak demikian. Kebebasan, di dunia manapun tidak akan pernah menamukan kemutlakannya. Tentu kebebasan akan selalu bermakna relatif. Selama manusia hidup dalam kehidupan sosial, bermasyarakat dan bernegara, maka kebebasan selalu berada dalam syarat dan limitasi. Limitasi yang paling mudah diterima adalah limitasi bahwa kenbebasan tersebut jangan sampai menghalangi juga kebebasan orang lain. Dengan kata lain, kebebasan yang sebebas-bebasnya bukan lagi ekspresi hak asasi, termasuk hak asasi yang paling asasi ialah hal terkait kepemelukan terhadap suatu keyakinan. Justeru kebebasan yang mutlak itu akan menjadi pelanggaran dan pencederaan terhadap hak asasi orang yang boleh jadi jumlahnya lebih banyak.

Memang harus diyakini, bahwa agama adalah suatu hal yang sangat abstrak atau sublim. Dan agama, merupakan suatu aspek yang memiliki karakter khas, meminjam ungkapan Peter L Berger, agama adalah "sacred canopy" (payung sakralitas) yang akan mampu mewujudkan cara pandang yang unik bagi pemeluklnya. Makanya ketersinggungan seseorang atau komunitas tertentu atas suatu tindakan yang dinilai merendahkan agamanya, terkadang dinilai sebagai sesuatu yang absurd bagi orang di luar agamanya.

Keluarnya Penetapan Presiden Republik Indonesia Nomor 1 Tahun 1965 Tentang Pencegahan Penyalahgunaan Dan/Atau Penodaan Agama, atau yang secara singkat sering idsebut dengan PNPS no 1 tahun 1965, telah memberikan sebuah 'tafsir' bagi kebebasan

17 Keputusan Bersama Menteri Agama, Jaksa Agung, Dan Menteri Dalam Negeri Republik Indonesia Nomor : 3 Tahun 2008 Nomor : Kep-033/AJJV6/2008 Nomor : 199 Tahun 2008 Tentang Peringatan Dan Perintah Kepada Penganut, Anggota, Dan/Atau Anggota Pengurus Jemaat Ahmadiyah Indonesia (JAI) Dan Warga Masyarakat.

18 Majelis Permusyawaratn Rakyat Republik Indonesia, UndangUndang Dasar Negara Republik Indonesia Tahun 1945 Dalam Satu Naskah 
yang dijamin dalam konstitusi, artinya bahwa kebebasan tersebut pada realisasinya tidak mutlak. Dalam PNPS no 1 tahun 1965, pelarangan terhadap aliran ajaran tertentu yang dinilai 'menyinggung' perasaan pemeluk agama lainnya telah ditegaskan. PNPS ini, memang menjadi kontroversi. Pihak yang pro plurasime liberal berpendapat bahwa apa yang diatur dalam PNPS sebenarnya suatu hal yang berlebihan, bahwa negara terlalu jauh mencampuri urursan agama, yang mestinya merupakan domain privat.

Karenanya, keluarnya PNPS tersebut merupakan kesalahan masa lalu yang harus segera diperbaiki (dicabut atau diamandemen). Dalam pandangan pihak ini, kebebasan agama adalah hak yang sangat asasi, dan jaminan dalam UUD 1945 dinilai sudah sangat jelas, dan justeru PNPS ini bertentangan dengan UUD 1945 tersebut. Atas dasar itulah, maka pihak ini kemudian mengajukan permohonan judicial review. ${ }^{19}$

Permohonan uji materi (judicial review) atas PNPS no. 1 Tahun 1965 itu diajukan oleh beberapa individu dan sebagian atas nama kelompok tertentu. Uji materi UU tentang Pencegahan, Penyalahgunaan, atau Penodaan Agama diajukan oleh sejumlah aktivis HAM. Mereka adalah Rachland Nashidik (Imparsial) Asmara Nababan (Elsam), Syamsuddin Radjab (PBHI), Anton Pradjasto (Pusat Studi HAM dan Demokrasi), Hendardi (Setara Institute), Muhammad Nur Khoiron Desantara Foundation, Patra Mijaya Zen (YLBHI), Gus Dur, Musdah Mulia, Dawam Rahardjo, dan Maman Imanul Haq. ${ }^{20}$

\section{ALASAN PEMOHON UJI MATERIIL}

Pada prinsipnya, keberatan atas PNPS No. 1 Tahun 1965 tersebut menyandarkan pada bahwa semua manusia memiliki kedudukan yang sama di depan hukum, bahwa semua warga Negara memiliki kebebasan untuk menganut keyakinan apapun yang dikehendakinya. Sedangkan pada sisi lainnya, undang-undang tersebut memberikan pembatasan atas macam agama yang dapat diamalakan dan diikuti di wilayah Republik Indonesia. Sehingga, secara selintas, undang-undang tersebut bersifat diskriminatif.

Norma materiil yang diujikan adalah Pasal 1, Pasal 2 ayat (1) dan ayat (2), Pasal 3 dan Pasal 4. Pasal-pasal yang diatur dalam UU a quo tersebut dinilai bertentangan dengan UUD 1945 yakni menyangkut persamaan dalam hukum (equality before the law) yang dijamin dalam Pasal 27 ayat (1) UUD 1945, Pasal 28D ayat (1) UUD 1945, Pasal 28I ayat (2) UUD 1945, Pasal 28E ayat (1) dan (2) UUD 1945.

Pemohon menilai, Pasal 1 UU a quo bersifat diskriminatif karena menunjukkan pembedaan dan pengutamaan terhadap enam agama yakni: Islam, Katolik, Kristen, Hindu, Budha, dan Kong $\mathrm{Hu} \mathrm{Cu}$, dibandingkan dengan agama-agama atau aliran keyakinan lainnya. Aturan tersebut dinilai pemohon bertentangan dengan Pasal 28I ayat (2) UUD 1945. Dengan demikian, pemohon menilai dengan sendirinya ketentuan Pasal 2 ayat (2) UU a quo sebagai hukum proseduralnya juga bertentangan dengan UUD 1945.

\section{ALASAN YANG KONTRA TERHADAP ALASAN PEMOHON}

Salah satu argument yang diajukan oleh pihak yang mengajukan keberaatan dengan larangan penodaan agama adalah, bahwa pasal tersebuttelah menjadikan terjadinya kekerasan antara orang beragama. Pernyataan tersebut tidak akurat dan misleading. Kekerasan tidak ada kaitannya dengan hal itu, kekerasan adalah urusan bagaimana perbedaan itu harus dikelola. Adalah suatu logika yang mengandung contradictio interminis jika penodaan agama harus dihapus, sementara perbuatan tidak menyenangkan saja diatur dalam banyak undang-undang

19 "MK Akan Minta Pandangan Ahli Tentang Penodaan Agama" dalam Berita Mahkamah Konstitusi 3 Pebruari 2010. www. mahkamahkonstitusi.ao.id. Akses 12 Pebruari 2010.

20 lbid 
pidana di dunia dan itu dinilai tanpa masalah. Adalah sesuatu yang wajar jika orang tidak ingin mendapat penghinaan dalam beragama.

Mencoba membolehkan berbagai aliran diterima apa adanya batasan yang pasti hanya atas alasan kekebasan berekspressi adalah cermin dari ketidakmampuan negara untuk mengelola masalah yang muncul dari masyarakat. Sehingga hal ini akan membahayakan kehidupan beragama. Hal tersebut, dilihat dari berbagai sisi tidak dapat diterima. Ada beberapa alasan yang harus dipertimbngakan.

Dalam setiap masyarakat beragama, penodaan agama adalah suatu yang tabu dan harus dihindari. Agama adalah identitas yang paling hakiki, itulah mengapa kebebasan beragama (dan tentunya kenyamanannya) dijamin dalam banyak kovenan, traktat, atau konstitusi di mana saja. Artinya, keberadaan agama sebagai suatu khazanah pribadi dan sosial yang paling radiks telah disadari sejak lama. Kesadaran ini bermakna pula bahwa pencederaan terhadap agama (violations) juga merupakan tindakan yang mesti dihindari.

Masyarakat yang plural, tidak berarti bahwa agama harus didegradasikan dalam tingkat di mana fanatisme kegamaan tersegregasi dari pribadi orang. Agama adalah tetap sebagai keyakinan dan sekaligus identitas yang melekat pada pemeluknya. Sehingga rasa kecintaan kepada agama adalah hal yang wajar juga. Jika kemudian agama seseorang di imitasi oleh orang lain, dengan pengubahan ajaran yang sangat bertentangan dengan sumber yang autoritatif dari agama tersebut, maka tentu saja akan terjadi ketersinggungan. ${ }^{21}$

Dari segi yuridis dapat juga dikatakan bahwa adalah Pasal 1, Pasal 2 ayat (1) dan ayat (2), Pasal 3 dan Pasal 4, UU No. 1 tahun 1965 tersebut sulit untuk dikatakan bertentangan dengan berbagai ketentuan kebebasan beragama atau kebasan dari perlakuan diskriminatif. Hal ini dikarenakan, dalam setiap hak asasi, terkandung kebebasan yang sangat luas, namun bukan berarti kebebasan tersebut harus tanpa batas, sangat perlu untuk dibatasi. Dari segi hukum juga, bahwa beberapa pasal dari undang-undang tersebut merupakan lex specialis, artinya pengkhususan atas sesuatu yang dikecualikan dari prinsip umumnya. Dan sekali lagi, hal ini sangat wajar dan dapat diterima dengan akal sehat.

Wajarlah jika kemudian jika permohonan Judicial Review terkait Undang-Undang Penodaan Agama ini kemudian ditolak oleh Mahkamah Konstitusi. ${ }^{22}$ Tentu saja setelah mempertimbangkan banyak argumen dan amasukan, baik yang diberikan oleh oleh para saksi ahli, serta tentu saja berbagai potensi masalah yang dapat saja muncul jika permohonan uji materi tersebut dikabulkan.

\section{KESIMPULAN}

Dari diskusi tentang berbagai pendapat dan argumentasi di atas, nampak bahwa ada berbagai dasar yang menjadikan alasan dari pendapat yang menyeruak, baik alasan yang sifatnya kontra terhadap larangan agama aliran tertentu maupun alasan yang mendukung atau sepakat dengan pelarangan tersebut. Dari paparan di atas dapat diambil kesimpulan bahwa pihak yang menyetujui adanya kebebasan beragama, dan termasuk di dalamnya memeluk suatu aliran kepercayaan tertentu, beralasan bahwa kedudukan semua warga negara sama di depan hukum, yang karenanya mereka mestinya memiliki hak yang sama untuk memeluk agama apapun yang dikehendakinya.

${ }^{21} \mathrm{Hal}$ ini juga sejalan dengan pendapat Kementerian Agama (dahulu Departemen Agama), karena memang jika tidak ada aturan tersebut, penodaan agama tidak aakan dapat dilarang. "Menag Yakin MK Tolak Gugatan Uji Materi UU Penodaan Agama", dalam, Kominfo-Newsroom 12/2/2010. Akses 12 Pebruari 2010.

22 "JR UU Penodaan Agama Ditolak, Putusan MK Dikhawatirkan Jadi Angin Segar Pelanggengan Diskriminasi," dalam www.detiknews.com Selasa, 20/04/2010. Akses, 6 Mei 2014. 
Karenanya, semuabentukperaturan perundang-undanganyang dipandang menghalangi mestinya harus dinyatakan tidak dapat berlaku. Permohonan uji materiil terhadap suatukontra terhadap UU no.1 tahun 1965 Tentang Pencegahan Penyalahgunaan dan/atau Penodaan Agama adalah upaya hukum yang dilakukannya.

Di sisi lain, dalam teori hukum dan hak asasi apapun juga, kebebasan selalu saja mengandung limitasi yang tidak dapat dilanggar, ialah kebebasan adalah hak yang harus dihormati selama tidak dalam keadaan melanggar hak orang lain. Maka, masalah kebebasan menganut suatu agama atau kepercayaan harus dilakukan dengan cara yang tidak melukai perasaan agama yang lain. Di sinilah relevansi penolakan uji materi terhadap kebebasan beragama yang antara lain mengambil momentum dengan perlawanan terhadap pelarangan gerakan Ahmadiyah dimana hal ini juga dilarang di berbagai negara di dunia. ***

\section{BIBLIOGRAFI}

\section{Literatur}

Agustian, Ary Ginanjar, Emotional, Spiritual Quotient, Jakarta: Arga Publishing, 2010, him. 11.

Ahmad, Shaikh Khurshid (Translation, Zakaria Virk ), A Brief History of Ahmadiyya Muslim Community (For Ahmadi Children), dalam, http://www.alislam.oral, diakses 11 September 2011.

Berger, Peter L, The Sacred Canopy, Elements of a Sociological Theory of Religion, New YorkLondon : Anchor Book Doubleday, 1990

Brownlie, Ian, Basic Documents on Human Rights,Oxford: Offord University Press, 1992

Davis, Charles, Religion Making Society, Cambridge :Cambridge University Press, 1994

Firth, Raymond, Religion, a Humanist Interpretation, London : Routledge, 1996.

Graham, L. Bennett, Defamation Of Religions: The End Of Pluralism?, dalam, www.law. emorv.edu Diakses 9 Maret 2010, hlm. 81.

Kearns, Paul, "The End of Blasphemy Law," dalam Amius Curiac Issue 76, Winter 2008. HIm. 25 dalam, www.sas-space.sas.ac.uk, diakses, 9 maret 2010

Mazrui, Ali A, The Satanic Verses or a Satanic Novel? Moral Dilemmas of the Rushdie Affair, hlm., 5-6.dalam www.angelfire.com rebellion2...SalmanRushdie satanic verses.pdf, diakses 11 September 2011.

Osman, Firoz, "Satanic Verses: Freedom of Speech Does not Offer Right to Blaspheme,", dalam Media Monitors Network, dalam, www.mediamonitors.net , diakses 11 September 2011.

Paden, William E, Religious Worlds, The Comparative Study of Religion, Boston : Beacon Press, 1998

Shiddiqi, N, Piagam Madinah, Yogyakarta: Mentari Masa, 1989

The Hutchinson Dictionay of World History, Oxford: Helicon Poblishing, 1998 
The Magna Charta, The Original Version of this Text was Rendered into HTML by Jon Roland of the Constitution. Society, dalam www.constitution.ora/enal Akses 5 Mei 2014.

$\mathrm{Jr}, \mathrm{W}$. Cole Durham, The Right to Autonomy in Religious Affairs: A Comparative View, dalam www.strasbouraconsortium.org him. 2 dan 10. Akses, 6 Mei 2014

"JR UU Penodaan Agama Ditolak, Putusan MK Dikhawatirkan Jadi Angin Segar Pelanggengan Diskriminasi," dalam www.detiknews.com Selasa, 20/04/2010. Akses, 6 Mei 2014.

"Menag Yakin MK Tolak Gugatan Uji Materi UU Penodaan Agama", dalam, Kominfo-Newsroom 12/2/2010. Akses 12 Pebruari 2010.

"MK Akan Minta Pandangan Ahli Tentang Penodaan Agama" dalam Berita Mahkamah Konstitusi 3 Pebruari 2010. www.mahkamahkonstitusi.go.id. Akses 12 Pebruari 2010.

\section{Perundang-Undangan}

Penetapan Presiden Republik Indonesia Nomor 1 Tahun 1965 Tentang Pencegahan Penyalahgunaan Dan/Atau Penodaan Agama, dimuat dalam Lembaran Negara Republik Indonesia Tahun 1965 Nomor 3.

Keputusan Bersama Menteri Agama, Jaksa Agung, Dan Menteri Dalam Negeri Republik Indonesia Nomor : 3 Tahun 2008 Nomor : Kep-033/A/JA/6/2008 Nomor : 199 Tahun 2008 Tentang Peringatan Dan Perintah Kepada Penganut, Anggota, Dan/Atau Anggota Pengurus Jemaat Ahmadiyah Indonesia (JAI) Dan Warga Masyarakat.

Majelis Permusyawaratn Rakyat Republik Indonesia, UndangUndang Dasar Negara Republik Indonesia Tahun 1945 Dalam Satu Naskah 